\title{
Removal of zinc and lead ions by polymer-enhanced ultrafiltration using unmodified starch as novel binding polymer
}

\author{
N. H. Baharuddin • N. M. N. Sulaiman • \\ M. K. Aroua
}

Received: 4 August 2013/Revised: 5 February 2014/ Accepted: 12 March 2014/Published online: 29 April 2014

(C) Islamic Azad University (IAU) 2014

\begin{abstract}
The removal of zinc and lead from aqueous dilute solutions by polymer-enhanced ultrafiltration process using unmodified starch as a new binding polymer was studied. Experiments were performed to determine the effects of transmembrane pressure, $\mathrm{pH}$, concentration of metal ions on the retention and permeate flux. The performance of the proposed new binding polymer was compared to that of polyethyleneimine a conventional polymer frequently used in polymer-enhanced ultrafiltration. The retention of zinc and lead ions reached 96 and $66 \%$, respectively, using $0.05 \%$ unmodified starch at $\mathrm{pH}$ 7. Overall unmodified starch showed better retention for zinc ions then polyethyleneimine, whereas polyethyleneimine retention for lead ions was higher. Solution $\mathrm{pH}$ was found to have little effect on flux.
\end{abstract}

Keywords Complexing agents - Metals .

Polyethyleneimine $\cdot$ Separation $\cdot$ Water soluble

\section{Introduction}

The problem of heavy metal contamination has become a crucial issue in water pollution because these metal elements impair marine ecosystems due to their relatively high densities and toxicity even at low concentrations. They persist in the aquatic environment which further increases their environmental impact. This water pollution causes adverse impacts on human beings and various biota species, because aquatic organisms are at high risk of

N. H. Baharuddin · N. M. N. Sulaiman · M. K. Aroua ( $ه)$ Department of Chemical Engineering, University of Malaya, 50603 Kuala Lumpur, Malaysia

e-mail: mk_aroua@um.edu.my exposure to the heavy metal contaminated water. Exposure of heavy metals increases the risk to aquatic organisms life even when those metals are detected at trace levels (Bosch 2003).

Water pollution due to heavy metal discharge into waterways is one of the issues faced in Malaysia. Out of the 464 rivers monitored, 275 (59.3\%) were found to be clean, $150(32.3 \%)$ slightly polluted and $39(8.4 \%)$ polluted (DOE 2011). All lead, $\mathrm{Pb}$ (II) and zinc, $\mathrm{Zn}$ (II) data were within class IIB limits of the National Water Quality Standard of Malaysia (NWQS). The most important of water management legislation in Malaysia is the Environmental Quality Act (EQA) applied for monitoring the quality of water resources.

Two of the metal elements found to be pervasive in water bodies are $\mathrm{Zn}$ (II) and $\mathrm{Pb}(\mathrm{II})$. Contamination of these two metals comes from industries such as smelting, mining, plating, manufacture of storage batteries, ceramic and glass. Based on the EQA, by the Department of Environment (DOE), the permissible effluent limit for industrial discharge for zinc and lead are 2 and $0.5 \mathrm{mg} / \mathrm{l}$, respectively (DOE 1994).

Removal of metal ions by complexation with watersoluble polymers and ultrafiltration is known as polymerenhanced ultrafiltration (PEUF). PEUF is known to have great potential for effectively removing metal ions from aqueous solutions (Ozbelge et al. 1997). Formation of metal ion-polymer complex is a crucial aspect for metal ion removal by PEUF process. The metal ions able to bind to polymer are retained by the membrane, whereas unbound metallic ions are allowed to pass through the membrane. Electrostatic attraction or electron coordination is the main contributor to the interaction of electron donors with acceptors that generate the metal ion-polymer bonds for metal ion-polymer complex formation (Khaidar et al. 
2009). Currently, application of PEUF for removal of metal ions has great potential to be explored further by researchers.

Most applications of PEUF focuses on the commonly used binding polymers such as polyethyleneimine (PEI), polyacrylic acid (PAA) and polyacrylic acid sodium salt (PAASS), which have been applied in heavy metal ion removal for decades via the ultrafiltration process (Islamoglu and Yilmaz 2006; Kadioglu et al. 2009). The preferred polymers for metal ions removal in PEUF system are mostly modified by crosslinking, grafting or any method that could change their molecular structure to enable reaction with metal ions to form macromolecules, hence easily removable from aqueous solutions ( $\mathrm{Hu}$ et al. 2009).

However, present modification of polymers with toxic chemicals can cause environmental pollution, which means that researchers did not realize they were creating new problems as they tried to overcome the heavy metals issue. Some researchers are focusing on modified starch such as insoluble starch xanthate and water-insoluble carboxylcontaining polymer for heavy metal ion removal (Chang et al. 2007; Doane et al. 1978) and in combination with filtration process (Kim and Lim 1999). The process to enhance reaction between metal ions and polymer will form high toxicity to the environment, especially after modification like insoluble starch xanthate (the process of xanthation of highly crosslinked starches prepared under various conditions) (Doane et al. 1975), which can cause acute toxicity (Alto et al. 1977) to biotic species in water bodies like rivers.

In this study, unmodified starch is proposed as a binding reagent for removal of target metals, namely $\mathrm{Zn}(\mathrm{II})$ and $\mathrm{Pb}$ (II) ions from aqueous solutions. Investigation of watersoluble starch as a biopolymer is a new application in complexation-ultrafiltration since to the best of our knowledge, there is no research in the open literature about water-soluble unmodified starch as a polymer in PEUF process. Less toxic polymers like unmodified starch could have high potential for metal ion removal from aqueous solution in the PEUF process. Hence, this unmodified starch is suitable as a potential binding reagent which has no adverse effect to the environment, as the sources are plant-based.

The common polymer, PEI, was also selected in this research besides unmodified starch for comparison purpose. In PEUF studies, one of the most important operating parameters is $\mathrm{pH}$. As indicated from previous studies, $\mathrm{pH}$ shows significant effects on flux and retention (Aroua et al. 2007). Generally, it is due to competition of hydrogen ions with metal ions, which can be trapped in the polymer structure at low $\mathrm{pH}$. Nevertheless, $\mathrm{pH}$ may influence retention by competing with metal ligands, resulting in high retention value for metal ion removal. As described by $\mathrm{Hu}$ et al. (2009), pH has great influence. In the study of cadmium removal, it was shown that increasing $\mathrm{pH}$ to a certain value can eliminate competing complexing agents that lead to fluctuation of retention and flux ( $\mathrm{Hu}$ et al. 2009).

This research was carried out between the 21st April 2010 and 30th August 2011 at the Department of Chemical Engineering, Faculty of Engineering, University of Malaya, Malaysia.

\section{Materials and methods}

\section{Materials}

Chemicals used in this experiment were unmodified starch in powder form and polyethyleneimine (PEI) $50 \%$ $(\mathrm{w} / \mathrm{v})$ in water as a binding reagent in the form of solutions (analytical grade) from ACROS Organics, zinc nitrate hexahydrate (MW: $297.46 \mathrm{~g} / \mathrm{mol}$ ) for preparation of $\mathrm{Zn}$ (II) solutions, lead nitrate (MW: $331.2 \mathrm{~g} / \mathrm{mol}$ ) for preparation of $\mathrm{Pb}(\mathrm{II})$ solutions, besides sodium hydroxide and hydrochloric acid for $\mathrm{pH}$ adjustment. Chemicals were used without further treatment. Dilutions and preparation of feed solutions were carried out using deionized water obtained using Millipore water purification system.

The membrane used was polysulfone hollow fibre from GE Healthcare (Model: UFP-10-C-MM06A) with an effective filtration area, A, of $26 \mathrm{~cm}^{2}$ with a molecular cut-off (MWCO) of $10 \mathrm{kDa}$ and a pure water permeate flux, Jw, of $0.9421 \mathrm{~cm} / \mathrm{min}$ after $20 \mathrm{~min}$ of operation at 1.5 bar. Polysulfone polymer is selected as the material of the membrane which is hydrophilic and generally designed for particulate removal from solutions during filtration. Before starting, each experimental water flux should be measured to ensure not more than $20 \%$ of reduction from the initial water flux reading and thus maintain the membrane performance in the ultrafiltration process.

\section{Apparatus}

In this study, a laboratory bench-scale system of crossflow filters was employed as shown in Fig. 1. The functional ultrafiltration process consists of the reservoir feed, retentate and permeates, which have been connected with tubing and backpressure valves, a peristaltic pump, manual pressure control clips and a flow meter with a digital panel meter/display, a stirrer for mixing and a power supply. For a $\mathrm{pH}$ measurement, a Metrohm $\mathrm{pH}$ meter was used. 

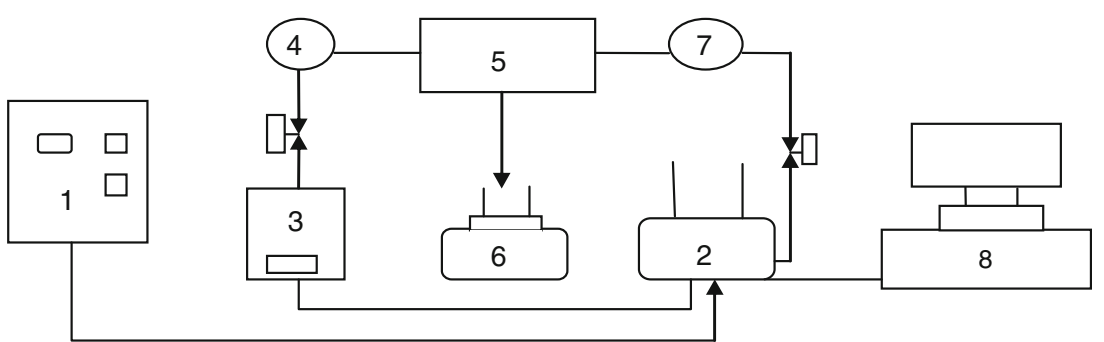

Fig. 1 Schematic diagram of laboratory-scale ultrafiltration system. (1) power supply and digital meter of flow rate, pressure in and out, (2) magnetic stirrer and $250 \mathrm{ml}$ of feed solutions, (3) peristaltic pump,

\section{UF experiments}

$\mathrm{Zn}$ (II) and $\mathrm{Pb}$ (II) were prepared as single metal ion solutions containing the desired amount of water-soluble polymer. The $\mathrm{pH}$ of the metal feed solutions was adjusted to the desired value by using $\mathrm{NaOH}$ or $\mathrm{HCl}$. In this work, low concentrations were used to avoid metal hydroxide precipitation that would influence negatively with the PEUF system. This can be clearly demonstrated in speciation studies that are explained further in the discussions. For mass effect studies, the amount of polymer used was $0.05-2.0 \%$ of starch and $0.01-2.0 \%$ of PEI with an overall concentration at $10 \mathrm{mg} / \mathrm{l}$ at a $\mathrm{pH}$ of 7 . In this study, the PEUF process was employed to find effects of important operating parameters for single metal solutions. All experimental work was conducted at 1.5 bar and $115 \mathrm{ml} /$ min of flow rate at room temperature of $26 \pm 1{ }^{\circ} \mathrm{C}$.

A feed volume of $250 \mathrm{~cm}^{3}$ was prepared. $\mathrm{pH}$, temperature, feed flow rate and pressure differences were monitored to be constant and were observed continuously during the UF process. The feed metal ion solution was kept stirred and circulated continuously through the peristaltic pump and passed through the hollow membrane fibre for $2 \mathrm{~h}$ all over the experiments. Although the feed concentration was adjusted for certain concentrations, the evaporation due to sampling from permeate or retentate may cause deviations. Thus, feed concentrations are regularly measured.

Retention values were calculated from the formula:

Retention coefficient, $R=1-\frac{C_{\mathrm{p}}}{C_{\mathrm{f}}}$

where $C_{\mathrm{p}}$ is the permeate concentration of the metal ion, and $C_{\mathrm{f}}$ is the feed concentration of metal. $C_{\mathrm{p}}$ is the average concentration of $\mathrm{Zn}(\mathrm{II})$ and $\mathrm{Pb}$ (II) ions in the permeate during the UF experiment.

Permeate flux is determined as follows:

Permeate flux

$=\frac{\text { Volume of permeate sample through membrane }}{\text { Effective area of membrane filtration } \times \text { time }}$
(4) pressure in, (5) hollow fibre filtration cell, (6) electronic balance and permeate solutions, (7) pressure out and (8) personal computer

At the end of the UF experiments, the membrane was immediately rinsed with ultrapure water obtained using Millipore water purification system and a sequence of $0.1 \mathrm{M}$ of $\mathrm{NaOH}$ and $0.1 \mathrm{M} \mathrm{NaOCl}$. Water flux should be continuously monitored to ensure the cleanliness of the membrane.

All experiments were carried out twice, and no significant differences were observed between the 2 runs (Table 1), in consequence, average value is used in this experiment.

\section{Analysis}

Inductively coupled plasma (ICP-OES) optical emission spectrometer (Model Optima 7000 DV) from Perkin-Elmer was used in this experiment to determine the concentrations of $\mathrm{Zn}$ (II) and $\mathrm{Pb}$ (II) in feed, retentate and permeate solutions. Standard metal solutions were prepared before the ICP runs, and average readings were recorded after three readings for each sample tested. The most important part was the calibration using standard solutions, where calibration should be accurate to at least over $95 \%$ for better results.

For speciation studies, Visual MINTEQ software version 3.0 is used to generate the speciation profiles for $\mathrm{Zn}$ (II) and $\mathrm{Pb}$ (II) ions. The software takes into account the solubility and precipitation equilibria; however, it only plots the speciation curves of soluble species.

\section{Results and discussion}

Speciation studies

The understanding of speciation profiles is important for investigation of the ionic species reactivity of metal solutions. Interpretation from species studies leads to identification of each ion charge that is present at a certain $\mathrm{pH}$ range. In this investigation, Visual MINTEQ software version 3.0 was used to produce species profiles for $\mathrm{Zn}$ (II) and $\mathrm{Pb}$ (II) both at the concentrations of $10 \mathrm{mg} / \mathrm{l}$. 
Table 1 Two set of data on the effect of $\mathrm{pH}$ on $10 \mathrm{mg} / \mathrm{l}$ concentration of $\mathrm{Zn}(\mathrm{II})$ and $\mathrm{Pb}$ (II) rejection and flux using $0.05 \%$ (w/v) unmodified starch and $0.01 \%(\mathrm{v} / \mathrm{v})$ PEI as water-soluble polymer

\begin{tabular}{|c|c|c|c|c|c|c|c|c|c|c|c|c|}
\hline \multirow{4}{*}{$\begin{array}{l}\text { Metal ions } \\
\mathrm{pH}\end{array}$} & \multicolumn{6}{|c|}{ Rejection, $R(\%)$} & \multicolumn{6}{|c|}{ Flux, $J\left(10^{-2} \mathrm{~cm} / \mathrm{min}\right)$} \\
\hline & \multicolumn{3}{|l|}{$\mathrm{Zn}(\mathrm{II})$} & \multicolumn{3}{|l|}{$\mathrm{Pb}(\mathrm{II})$} & \multicolumn{3}{|l|}{$\mathrm{Zn}(\mathrm{II})$} & \multicolumn{3}{|l|}{$\mathrm{Pb}(\mathrm{II})$} \\
\hline & \multicolumn{12}{|c|}{ Readings } \\
\hline & 1 & 2 & Average & 1 & 2 & Average & 1 & 2 & Average & 1 & 2 & Average \\
\hline \multicolumn{13}{|l|}{ Unmodified starch } \\
\hline 2 & 84.332 & 88.630 & 86.481 & 58.113 & 60.373 & 59.243 & 11.006 & 10.438 & 10.722 & 18.245 & 18.899 & 18.572 \\
\hline 5 & 94.875 & 95.551 & 95.213 & 54.098 & 54.328 & 54.213 & 10.564 & 9.498 & 10.031 & 17.985 & 18.861 & 18.423 \\
\hline 7 & 95.167 & 97.011 & 96.089 & 61.567 & 62.731 & 62.149 & 10.074 & 9.828 & 9.951 & 17.698 & 18.530 & 18.114 \\
\hline 9 & 89.315 & 89.115 & 89.215 & 53.421 & 55.483 & 54.452 & 9.342 & 9.702 & 9.522 & 15.092 & 15.792 & 15.442 \\
\hline 12 & 82.314 & 79.284 & 80.799 & 41.268 & 44.194 & 42.731 & 7.332 & 7.690 & 7.511 & 12.956 & 13.546 & 13.251 \\
\hline Mean & 89.201 & 89.918 & 89.559 & 53.693 & 55.422 & 54.558 & 9.664 & 9.431 & 9.547 & 16.395 & 17.126 & 16.76 \\
\hline Variance, $\alpha^{2}$ & 34.735 & 49.357 & 40.235 & 59.039 & 51.301 & 54.895 & 2.080 & 1.070 & 1.481 & 5.293 & 5.680 & 5.483 \\
\hline Standard deviation, SD & 5.894 & 7.025 & 6.343 & 7.684 & 7.162 & 7.409 & 1.442 & 1.034 & 1.217 & 2.301 & 2.383 & 2.342 \\
\hline \multicolumn{13}{|l|}{ PEI } \\
\hline 2 & 76.648 & 77.656 & 76.984 & 59.004 & 60.519 & 59.761 & 13.221 & 14.127 & 13.674 & 20.896 & 21.372 & 21.134 \\
\hline 5 & 74.205 & 74.533 & 74.314 & 73.763 & 74.863 & 74.313 & 14.217 & 14.829 & 14.523 & 20.993 & 21.257 & 21.125 \\
\hline 7 & 91.103 & 90.738 & 90.981 & 81.060 & 80.722 & 80.891 & 15.456 & 16.186 & 15.821 & 20.002 & 23.180 & 21.591 \\
\hline 9 & 85.680 & 87.010 & 86.123 & 78.675 & 79.754 & 79.214 & 13.227 & 14.117 & 13.672 & 15.976 & 17.590 & 16.783 \\
\hline 12 & 83.667 & 85.005 & 84.113 & 83.816 & 85.016 & 84.416 & 10.124 & 10.146 & 10.135 & 15.349 & 16.343 & 15.846 \\
\hline Mean & 82.260 & 82.988 & 82.503 & 75.263 & 76.175 & 75.719 & 13.249 & 13.881 & 13.565 & 18.643 & 19.948 & 19.296 \\
\hline Variance, $\alpha^{2}$ & 47.062 & 45.056 & 46.273 & 96.255 & 89.623 & 92.809 & 3.894 & 5.070 & 4.449 & 7.602 & 8.186 & 7.552 \\
\hline Standard deviation, SD & 6.860 & 6.712 & 6.802 & 9.811 & 9.467 & 9.634 & 1.973 & 2.252 & 2.109 & 2.757 & 2.861 & 2.748 \\
\hline
\end{tabular}

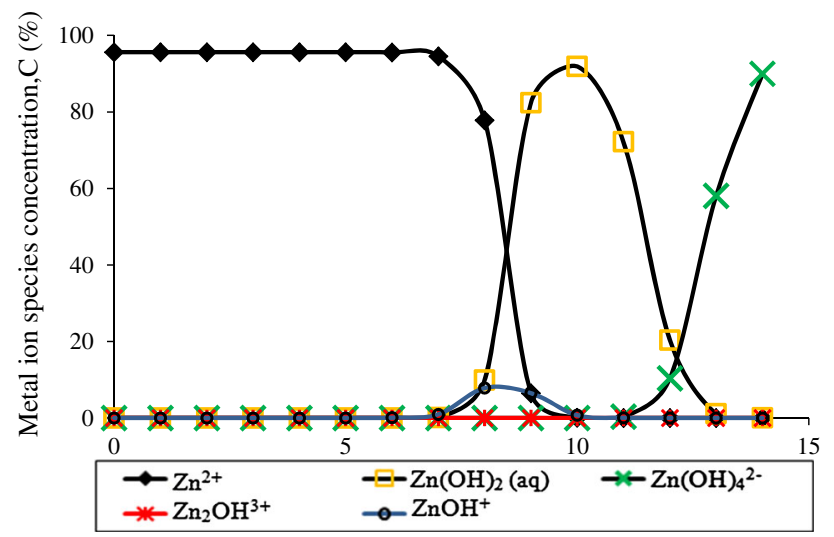

Fig. 2 Speciation profiles of $\mathrm{Zn}(\mathrm{II})(\mathrm{Zn}(\mathrm{II})$ concentration $=10 \mathrm{mg} / \mathrm{l})$

\section{Speciation profile of $\mathrm{Zn}(I I)$}

Figure 2 shows the speciation profile of $10 \mathrm{mg} / \mathrm{l}$ concentration for $\mathrm{Zn}(\mathrm{II})$. As shown in this figure, five soluble metal species of $\mathrm{Zn}(\mathrm{II})$ are identified, and their presence depends on the solution $\mathrm{pH} . \mathrm{Zn}^{2+}$ appeared as a major species until $\mathrm{pH} 7$ and represents $96 \%$ of the concentration for total zinc. Only $\mathrm{Zn}_{2}(\mathrm{OH})^{+3}$ cationic species appear at the entire $\mathrm{pH} 7$ range and above. Besides monovalent species, $\mathrm{Zn}(\mathrm{OH})^{+}$ only appears at $\mathrm{pH} 8$ and $\mathrm{pH} 9$. Insoluble $\mathrm{Zn}(\mathrm{OH})_{2}$ becomes the major component when the $\mathrm{Zn}^{2+}$ species disappears at

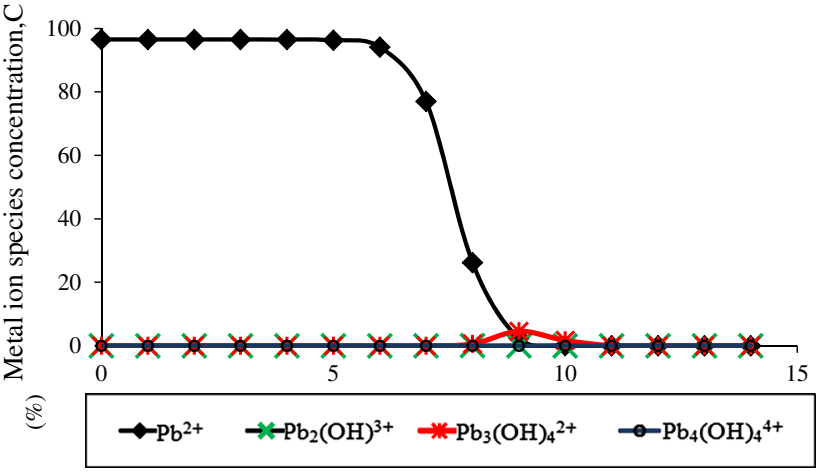

Fig. 3 Speciation profiles of $\mathrm{Pb}(\mathrm{II})(\mathrm{Pb}(\mathrm{II})$ concentration $=10 \mathrm{mg} / \mathrm{l})$

$\mathrm{pH} 10$. These species disappear at $\mathrm{pH} 13$, and $\mathrm{Zn}$ (II) takes the form of $\mathrm{Zn}(\mathrm{OH})_{4}^{-2}$. $\mathrm{Zn}(\mathrm{OH})_{4}^{-2}$ species become the only species at $\mathrm{pH} 13$ and above.

\section{Speciation profiles of $\mathrm{Pb}(\mathrm{II})$}

Speciation profiles for $\mathrm{Pb}(\mathrm{II})$ are given in Fig. 3. As clearly shown in this figure, four soluble species of $\mathrm{Pb}$ (II) exist at different $\mathrm{pH}$.

For $\mathrm{pH}$ up to 6 , about $98 \%$ of $\mathrm{Pb}$ (II) exist as $\mathrm{Pb}^{2+}$. This species disappears at $\mathrm{pH} 9 . \mathrm{Pb}_{3}(\mathrm{OH})_{4}^{2+}$ concentration is very low at almost the entire $\mathrm{pH}$ range with a slightly high 


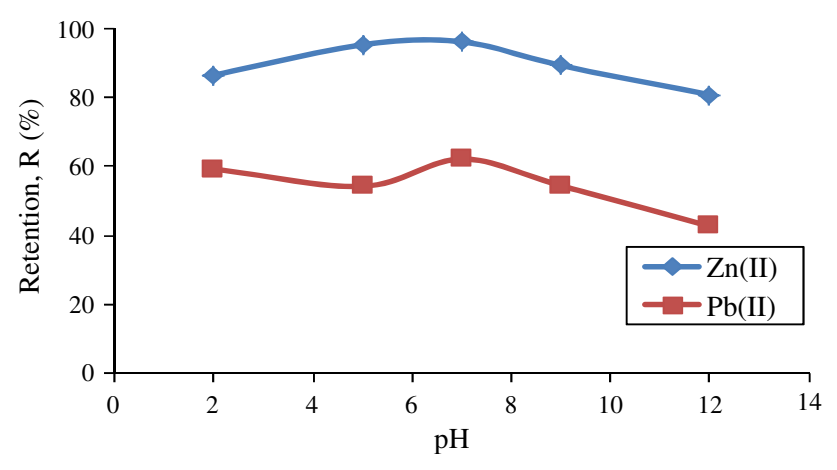

Fig. 4 The effect of $\mathrm{pH}$ on $10 \mathrm{mg} / \mathrm{l}$ concentration of $\mathrm{Zn}$ (II) and $\mathrm{Pb}$ (II) rejection using $0.05 \%(\mathrm{w} / \mathrm{v})$ unmodified starch

concentration at $\mathrm{pH}$ 9. The concentrations of the two other species namely $\mathrm{Pb}_{2}(\mathrm{OH})^{3+}$ andPb $4(\mathrm{OH})_{4}^{4+}$ are very low and can be considered negligible over the entire range of $\mathrm{pH}$.

Effect of $\mathrm{pH}$ on $\mathrm{Zn}(\mathrm{II})$ ion retention by polymerenhanced ultrafiltration

\section{Effect of $p H$ on $\mathrm{Zn}(\mathrm{II})$ retention using unmodified starch}

Figure 4 shows the effects of $\mathrm{pH}$ on rejection of $\mathrm{Zn}$ (II) and $\mathrm{Pb}$ (II) ions using unmodified starch. The studied $\mathrm{pH}$ range was from 2 to 12, and applied pressure was 1.5 bar at room temperature. Almost all rejections of $\mathrm{Zn}(\mathrm{II})$ were higher than $\mathrm{Pb}$ (II) for entire range of $\mathrm{pH}$ tested, but decreased above $\mathrm{pH}$ 7. As $\mathrm{pH}$ increased, the formation of the complexes is enhanced and eventually increase the $\mathrm{Zn}(\mathrm{II})$ retention (Barakat and Schmidt 2010). It is due to an adsorptive mechanism for a metal ion by unmodified starch is most probably caused by a physical mechanism of adsorption, where metal ions are able to bind to the starch surface.

There are high possibilities that the adsorption process is a chemical adsorption. The binding of starch generally influenced by two polysaccharide groups, namely amylose and amylopectin, where amylopectin represents a highly branched (70-80 \%) molecular structure (Hoover 2001) in consequence, has a high possibility to be crumpled and lose the structure (Eilers 1936) and able to allow penetration of metal ions onto the surface molecules (Chabot and Hood 1976).

At pH 7 with unmodified starch as binding biopolymer, $\mathrm{Zn}$ (II) removal meets permissible limits for the discharged effluent standard of the EQA which is $96 \%$ removal representing $0.4 \mathrm{mg} / \mathrm{l}$ by employed PEUF process in metal ions removal.

Unmodified starch uptake of selected metal ions by adsorption is high at certain working conditions are due to chemical adsorption. The metal component is bounded to the unmodified starch because of hydrogen ions forming a number of pendant hydroxyl $(\mathrm{OH})$ groups capable to form hydrogen bonds. $\mathrm{H}+$ at position 2, 3 and 6 in glucose is capable of forming donor bonds to complex metal ions. Hence, there is a high possibility that the adsorption can occur via chemical interactions as expressed in Eqs. 3 and 4: $X$ represents hydrogen ions; Me represents metal ion.

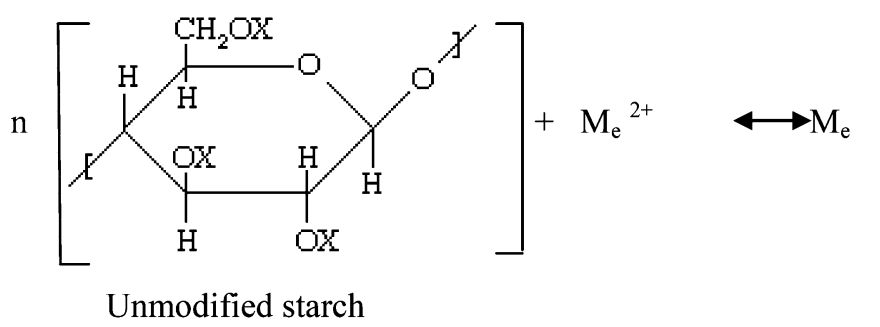

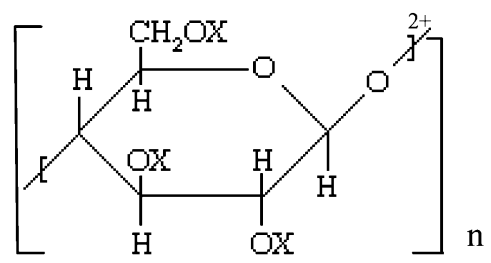

Unmodified starch

$\mathrm{n}$

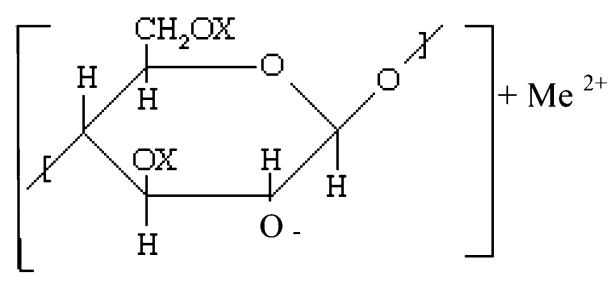

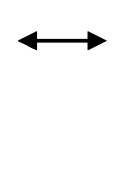

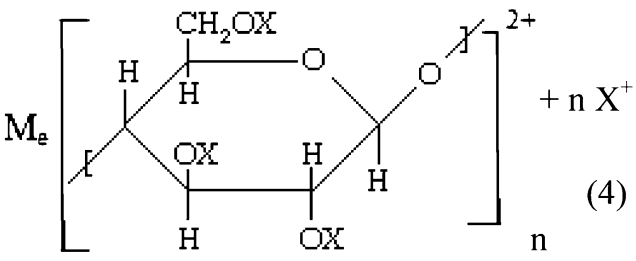

Hydrogen at 2- $\alpha$ glucose 
As expected, metal rejection was highly dependent on the solution $\mathrm{pH}$, being lower at low $\mathrm{pH}$ range due to the competing protons for available active sites of the macromolecular ligand which causes the loss of the $\mathrm{Zn}(\mathrm{II})$ complex stability (Camarillo et al. 2012).

Increase in $\mathrm{pH}$ resulted in an increase in the retention up to $96 \%$ at $\mathrm{pH}$ 7. This is in concordance with the study of Bertolini who found that the solubility of $\mathrm{Zn}$ (II) ions in most types of waters is greater at range 7.0-9.2, in consequent, its ability to be bound to starch is better at this $\mathrm{pH}$ range.

When the solution $\mathrm{pH}$ is increased above $7, \mathrm{Zn}$ (II) ions retention is decreased. This is might be due to the negative effect of the insoluble metal hydroxides. Furthermore, at such high $\mathrm{pH}$, most probably starch granular reaction takes place and produce heterogeneous granular patterns which reduces the metal ions ability to diffuse into and disperse throughout the granule matrix prior to slow reaction between metal ions-polymer (BeMiller and Huber 2001, BeMiller and Gray 2004). Theoretically, as $\mathrm{pH}$ is increased, the reaction efficiency should increase (BeMiller and Gray 2005; BeMiller and Han 2007; Beenakers et al. 1994; Lim and Seib 1993; Seib and Wu 1990), but at certain $\mathrm{pH}$ range, the granular reaction pattern of starch to metal ion and species of metal ions exists in solution effect the ability of metal ions in adsorb to starch (Bertolini 2010; Aratani et al. 1983) is decreased.

Unmodified starch has characteristic of long chains and possible as forked and branched structure provides the side group of the macromolecule that can attract each other strongly. The long chains structure can eventually shorten the molecule by physical adsorption. As the structure of molecule would not pack as straighter chain as those cellulose, it has ability to lose the structure to provide chance for solvent to penetrate; results in starch being able to bond, hence increasing its molecular weight and form macromolecules structure in consequence being able to be removed via PEUF, especially at low $\mathrm{pH}$ range.

The behaviour demonstrated for $\mathrm{Pb}$ (II) is similar to $\mathrm{Zn}$ (II) between $\mathrm{pH} 1$ and $\mathrm{pH}$ 7, and retention increases then starts to decrease gradually until $\mathrm{pH} 12$. From previous studies, adsorption of metal ions by the polymer increases as $\mathrm{pH}$ increases. It is mentioned that at neutral, in this case, $\mathrm{Pb}^{2+}$ is present, in concordance to $\mathrm{Pb}$ (II) speciation diagram or alkaline $\mathrm{pH}$ values interaction of metal ions with polymer can cause precipitation of metal hydroxide, but still metal ions are able to be removed via polymer-assisted ultrafiltration (Alpatova et al. 2004; Barakat and Schmidt 2010). They also concluded that at $\mathrm{pH}$ higher than 7 , most of $\mathrm{Pb}$ (II) species present in metal solutions are in low concentration, but still, the possibility for membrane fouling is high due to metal ion-polymer complexes that are

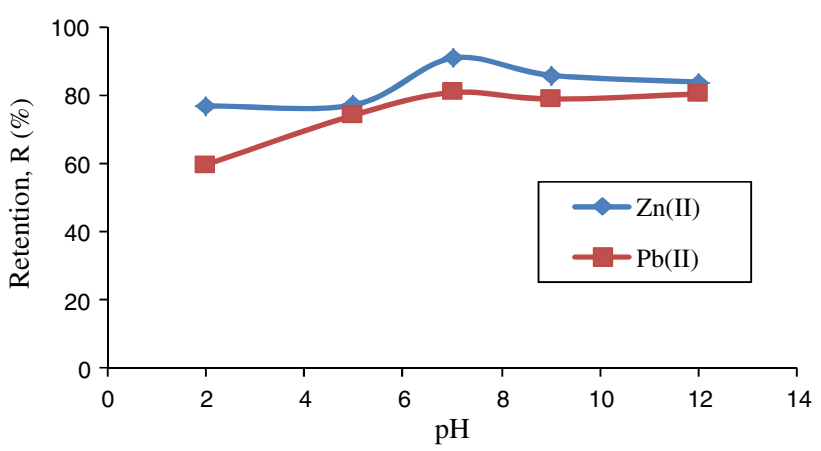

Fig. 5 Effect of $\mathrm{pH}$ on $10 \mathrm{mg} / \mathrm{l}$ concentration of $\mathrm{Zn}$ (II) and $\mathrm{Pb}$ (II) rejection using $0.01 \%(\mathrm{v} / \mathrm{v})$ PEI

able to completely retain on the membrane which enhances membrane pore blocking (Alpatova et al. 2004). At pH 10, $\mathrm{Pb}$ (II) ions retention is decreased due to the presence of three cationic species, namely $\mathrm{Pb}_{2}(\mathrm{OH})_{3}^{+}, \mathrm{Pb}_{3}(\mathrm{OH})_{4}^{2+}$ and $\mathrm{Pb}_{4}(\mathrm{OH})_{4}^{4+}$ (referred to speciation diagram), which cause desorption. This is due to the too low concentration of these three species to be bounded on the available macromolecular starch-PEI site.

\section{Effect of $p H$ on $\mathrm{Zn}(I I)$ and $P b(I I)$ retention using PEI}

Rejection values for metal ions are shown in Fig. 5 as the effect of $\mathrm{pH}$ on selected metal ion removal from aqueous solutions is determined by using PEI. It is clearly shown that the plots of graphs for both $\mathrm{Zn}(\mathrm{II})$ and $\mathrm{Pb}(\mathrm{II})$ are similar at an acidic $\mathrm{pH}$ to neutral $\mathrm{pH}$, but slightly differ at alkaline $\mathrm{pH}$ range. As PEI is a cationic polymer able to neutralize excess anionic species, retention achieves the highest rate as it reaches an alkaline $\mathrm{pH}$. This is in accordance with the speciation profile of $\mathrm{Zn}$ (II) species, where at a $\mathrm{pH}$ over $10, \mathrm{Zn}$ (II) with negatively charged species starts to appear. This contributes towards forming macromolecules by complexation, through interaction of the active amino group of PEI with $\mathrm{Zn}$ (II) ions.

The behaviour demonstrated for $\mathrm{Pb}(\mathrm{II})$ is slightly similar to that of $\mathrm{Zn}$ (II) where at an initial $\mathrm{pH}$ of 1 to $\mathrm{pH} 7$, retention is low due to presence of too high concentration $\mathrm{Pb}$ (II) ions. Repulsive interaction between PEI and $\mathrm{Pb}$ (II) occurs and then starts to reduce as $\mathrm{pH}$ reaches 10 . The presence of low concentration of $\mathrm{Pb}$ (II) species at this $\mathrm{pH}$ cause minimum repulsion between PEI and $\mathrm{Pb}(\mathrm{II})$. In consequence of, it influences adsorption resulting in an increase in $\mathrm{Pb}$ (II) ions uptake by $\mathrm{PEI}$ at $\mathrm{pH} 9$ and above. This PEI-Pb(II) interaction is in accordance with $\mathrm{Pb}(\mathrm{II})$ speciation profiles, which demonstrates existence of cationic species with low concentration in solution at $\mathrm{pH}$ ranges of 9 to $\mathrm{pH} 14$.

These cations cannot be completely complexed by the protonated PEI. Decrease in retention at lower $\mathrm{pH}$ 


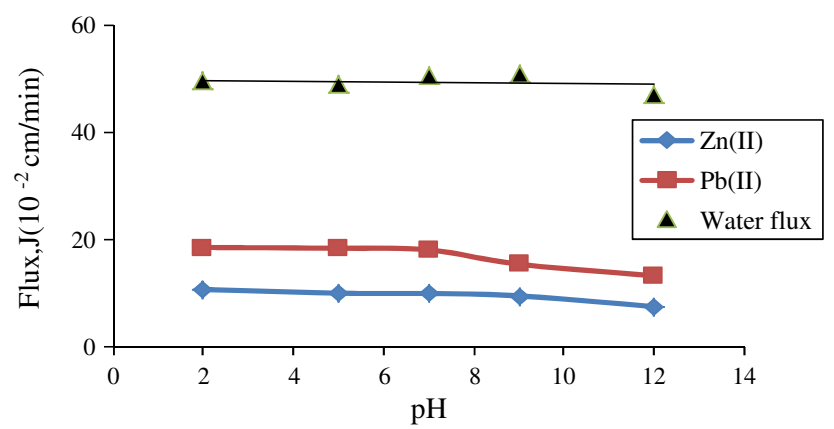

Fig. 6 Permeate water flux, $\mathrm{Zn}(\mathrm{II})$ and $\mathrm{Pb}(\mathrm{II})$ using $0.05 \%$ (w/v) unmodified starch at different $\mathrm{pH}$ values ( $\mathrm{Zn}$ (II) and $\mathrm{Pb}$ (II) concentration $=10 \mathrm{mg} / \mathrm{l}$ )

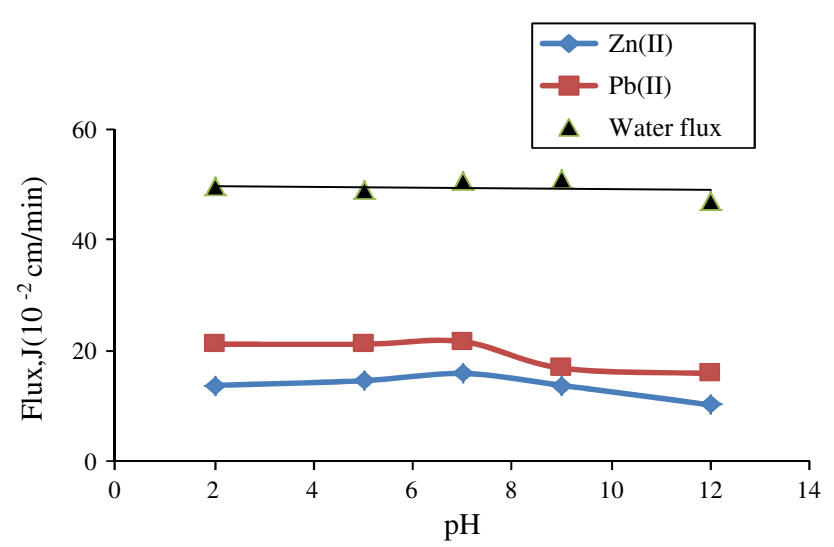

Fig. 7 Permeate water flux, $\mathrm{Zn}$ (II) and $\mathrm{Pb}(\mathrm{II})$ using $0.01 \%$ (v/v) PEI at different $\mathrm{pH}$ values $(\mathrm{Zn}(\mathrm{II})$ and $\mathrm{Pb}$ (II) concentration $=10 \mathrm{mg} / \mathrm{l}$ )

$(\mathrm{pH}<7)$ was connected with competition between $\mathrm{H}^{+}$and cationic $\mathrm{Pb}$ (II) forms. At acidic values of $\mathrm{pH}$, retention of $\mathrm{Pb}$ (II) decreased, but at alkaline $\mathrm{pH}$ values $\mathrm{Pb}$ (II) retention increased. It is due to lower concentration of cationic $\mathrm{Pb}$ (II) present in the solutions, hence low competition of $\mathrm{H}^{+}$and cationic $\mathrm{Pb}(\mathrm{II})$, resulting in increased retention. According to previous study by Aroua et al., by using PEI as binding polymer, retention increased as $\mathrm{pH}$ increased to up to $99 \%$ for $\mathrm{Cr}(\mathrm{III})$ ions removal and contrary with $\mathrm{Cr}(\mathrm{VI})$, where retention dropped as $\mathrm{pH}$ increased up to $\mathrm{pH} 12$ (Aroua et al. 2007).

\section{Effect of $\mathrm{pH}$ on PEUF flux}

Permeate flux is one of the important parameters in PEUF process. Figures 6 and 7 show membrane permeability for water, $\mathrm{Zn}$ (II) and $\mathrm{Pb}$ (II) using unmodified starch and PEI at various $\mathrm{pH}$ values. In both figures, the permeate flux is not significantly influenced by $\mathrm{pH}$. It is due to gel layer formation on membrane surface during the PEUF process for entire of tested $\mathrm{pH}$.

Lower permeate flux efficiency of $\mathrm{Zn}(\mathrm{II})$ ions indicates that the ability to form complexes with unmodified starch is

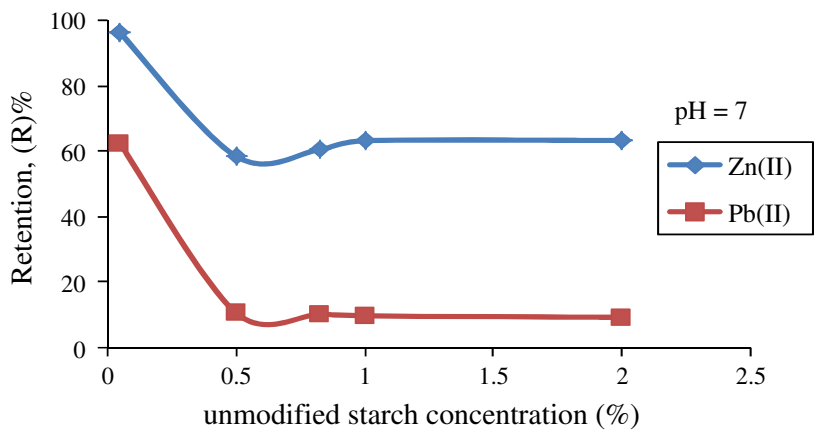

Fig. 8 Effect of unmodified starch concentration on $\mathrm{Zn}$ (II) and $\mathrm{Pb}$ (II) rejection $(\mathrm{Zn}(\mathrm{II})$ and $\mathrm{Pb}(\mathrm{II})$ concentration $=10 \mathrm{mg} / \mathrm{l})$

low due to the starch are able to form gelatinization, of which the starchy formation has resists on flow of metal ions complex solutions, hence negatively influenced on flux efficiency (Bello-Perez and Paredes-Lopez 2009).

From Figs. 6 and 7, it were observed that flux efficiency is slightly similar to $\mathrm{Zn}(\mathrm{II})$ and $\mathrm{Pb}$ (II) ions at various $\mathrm{pH}$ ranges (10-20\% of flux) using starch and PEI. This shows that the behaviour of gelatinization on unmodified starch does not significantly influence the permeate flux in PEUF system. The same results on flux showed by Aroua et.al, where $\mathrm{pH}$ has a little effect on flux efficiency in removal of chromium ions (Aroua et al. 2007).

Effect of polymer concentration on $\mathrm{Zn}$ (II) and $\mathrm{Pb}$ (II) ion retention by polymer-enhanced ultrafiltration

\section{Effect of unmodified starch concentration on $\mathrm{Zn}(I I)$ and $\mathrm{Pb}(\mathrm{II})$ retention}

All the samples of each selected metal solutions were prepared with same concentration $(10 \mathrm{mg} / \mathrm{l})$. Starch at different concentrations also prepared, and the effect of unmodified starch concentration on $\mathrm{Zn}$ (II) and $\mathrm{Pb}$ (II) removal were studied. All $\mathrm{pH}$ samples were adjusted at 7.0. From Fig. 8, it is plotted the metal solution retention for both tested metal ions at different starch concentrations.

Similar rejection patterns of $\mathrm{Zn}(\mathrm{II})$ and $\mathrm{Pb}$ (II) ions are shown in Fig. 8 due to many available complexing sites between polymer and metal ions at low starch concentrations. As polymer concentration increases, the ability of starch to bind with metal ions increases are due to availability of complexing sites is increased. The complexation metal ions and unmodified starch are observed to have great adsorption at lower polymer concentration at the same time can avoid the gelatinization behaviour.

The rejections consistently reach a plateau although starch concentration increases up to $1.0 \%$. Experimental results support theoretically, whereas higher concentration of polymer is applied, the polyelectrolyte behaviour causes 


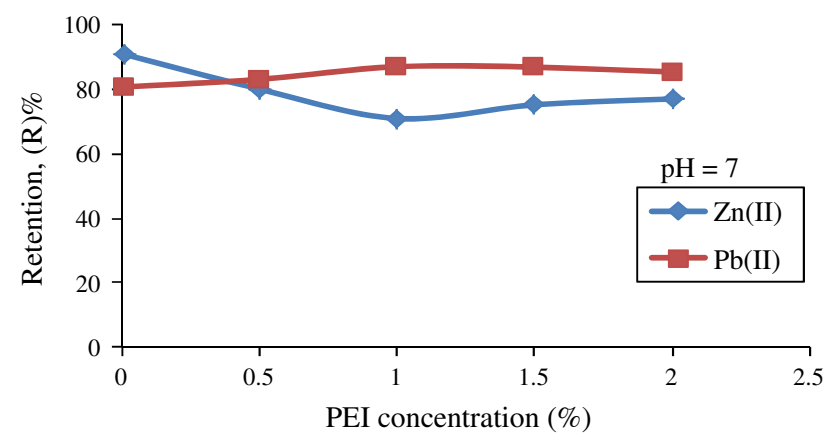

Fig. 9 Effect of PEI concentration on $\mathrm{Zn}$ (II) and $\mathrm{Pb}$ (II) rejection $(\mathrm{Zn}(\mathrm{II})$ and $\mathrm{Pb}(\mathrm{II})$ concentration $=10 \mathrm{mg} / \mathrm{l})$

the decrease in polyelectrolyte concentration. Hence, this phenomenon contributes towards the production of ions caused by low ionic atmosphere compared to diameter of polymeric coil because of the decrease in repulsive ions influencing the decrease in the chain rigidity. Hence, reluctant expand of polymeric coil causes a decrease in solution viscosity (Aroua et al. 2007). The reasons for employing low polymer concentrations are to minimize polymer losses and to have high metal ions retention (Bicak et al. 2013).

\section{Effect of PEI concentration on $\mathrm{Zn}(I I)$ and $\mathrm{Pb}(I I)$ retention}

Effect of PEI concentration on $\mathrm{Zn}$ (II) and $\mathrm{Pb}$ (II) rejection is shown in Fig. 9. It is demonstrated that $\mathrm{Zn}$ (II) ions influenced by PEI at low concentration and slight effects were obtained on $\mathrm{Pb}(\mathrm{II})$ ions rejection by increasing in PEI concentration to $2.0 \%$. This behaviour can be interpreted based on the previous finding of an adsorptive mechanism by complexation between several divalent metal cations and PEI (Kozuka et al. 1985). PEI has the ability to become one of the polymers with high complexation behaviour towards metal adsorption because it has an active group PEI of primary, secondary and tertiary imine groups in the ratio of 1:2:1 (Bolto 1995).

In our study, at very low value of PEI concentration, the equilibrium state of free $\mathrm{Zn}(\mathrm{II})$ ions with PEI is achieved; hence as PEI concentrations increases, the rejection decreases until a critical ratio, where the most favourable sites for metal ions are filled. A decrease in polymer concentration in consequence increases the solution viscosity, besides interacting with free amino groups and protonated PEI, which increases during optimum $\mathrm{pH}$ conditions. Interaction of uncharged PEI with metal ions may cause reduced viscosity because the influence of the backbone structure to form a coiled globule-like conformation (Pereira et al. 2003).
The rejection of $\mathrm{Pb}(\mathrm{II})$ ions obtained is almost constant despite an increase in PEI concentration. Number of PEI$\mathrm{Pb}$ (II) ion interaction indicates that the shear force formed by the recirculation feed of low polymer concentration in this study is due to blocking of macromolecules forming on the membrane surface (Ozbelge et al. 1997). From the previous study, rejection is slightly reduced at higher concentration of PEI and obtained the highest at $0.05 \%$ in removal of chromium ions (Aroua et al. 2007). From this investigation, low PEI concentrations can be exploited to achieve the highest rejection of $\mathrm{Zn}$ (II) and $\mathrm{Pb}$ (II) ions that are the most economical to be applied in wastewater treatment.

\section{Conclusion}

This PEUF study comprises removal of divalent metal ions of $\mathrm{Zn}$ (II) and $\mathrm{Pb}$ (II) in aqueous solutions. Beside the abundance of synthetic polymers available today, unmodified starch demonstrates immense potential as a binding polymer showing the best performance in removal of $\mathrm{Zn}$ (II) and $\mathrm{Pb}$ (II) over an acidic $\mathrm{pH}$ range and maximizing rejection at neutral $\mathrm{pH}$.

In this study, unmodified starch employed as watersoluble polymer has the ability to adsorb metal cations during ultrafiltration process without requiring any upgrade on the method of their molecular structure. No modification by means additional chemicals or molecular structure readjustment is not required in correspond to less toxicity of unmodified starch applied via PEUF system. High rejections of metal ions achieved whenever operated at room temperature. The ability of unmodified starch to reject metal ions is highly dependent on granular structure not the type of starch indicating a possibility of physical interaction not chemical.

Regarding the significant effects of $\mathrm{pH}$ as a factor in PEUF systems, results impressively showed that $96 \%$ of $\mathrm{Zn}(\mathrm{II})$ ion removal occurred at neutral $\mathrm{pH}$ as unmodified starch applied. In contrast, $\mathrm{Zn}$ (II) was found almost constantly when tested with synthetic polymer, PEI. For $\mathrm{Pb}(\mathrm{II})$, both selected polymers demonstrated little effect on rejection when tested over the entire $\mathrm{pH}$ region. Within the range of polymer concentrations tested in this study higher metal ion rejection is obtained low pH, $\mathrm{Zn}(\mathrm{II})$ ions reached about $96 \%$ rejection when $0.05 \%(\mathrm{w} / \mathrm{v})$ unmodified starch was used, afterwhich this rejection became constant. For $\mathrm{Pb}(\mathrm{II})$, rejections with unmodified starch achieved $87 \%$ of $\mathrm{Pb}(\mathrm{II})$ at a $1.0 \%(\mathrm{v} / \mathrm{v})$ of PEI concentration. Results indicate that unmodified starch could be the best water- 
soluble biopolymer for $\mathrm{Zn}(\mathrm{II})$ and $\mathrm{Pb}(\mathrm{II})$ removal from aqueous solutions.

Acknowledgments The authors acknowledge financial support from the University of Malaya, Kuala Lumpur, Malaysia through the Postgraduate Research Fund (PPP Grant) with grant PS 104-2010B and PV 092-2011B.

\section{Nomenclature}

$\begin{array}{ll}\text { MWCO } & \text { Molecular weight cut-off }(\mathrm{Da}) \\ \mathrm{PEI} & \text { Polyethyleneimine } \\ \mathrm{R} & \text { Rejection coefficient/retention } \\ \mathrm{A} & \text { Membrane area }\left(\mathrm{cm}^{2}\right) \\ \mathrm{Cp} & \text { Concentration of metal ion in permeate }(\mathrm{mg} / \mathrm{l}) \\ \mathrm{Cf} & \text { Concentration of metal ion in feed }(\mathrm{mg} / \mathrm{l}) \\ \mathrm{Me} & \text { Metal ion } \\ \mathrm{n} & \text { Coordination index of ligand L with metal Me } \\ \mathrm{x} & \text { Value number of metal molecule coordination } \\ \mathrm{PEUF} & \text { Enhanced Ultrafiltration } \\ \mathrm{Jw} & \text { Permeate water flux }(\mathrm{cm} / \mathrm{min})\end{array}$

\section{References}

Alpatova A, Bryk M, Hilal N, Nigmatullin R, Verbych S (2004) Ultrafiltration of water containing natural organic matter: heavy metal removing in the hybrid complexation-ultrafiltration process. Sep Purif Technol 40(2):155-162

Alto K, Broderius S, Lloyd L, Smith JR (1977) Toxicity of xanthates to freshwater fish and invertebrates. State of Minnesota, Environmental Quality Board, Department of Entomology, Fisheries, Wildlife, Minnesota

Aratani T, Kodukula P, Patterson JW (1983) Removal of metals in combined treatment systems. United States Environmental Protection Agency Report, Illinois Institute of Technology Chicago, Illinois

Aroua MK, Sulaiman NM, Zuki FM (2007) Removal of chromium ions from aqueous solutions by polymer-enhanced ultrafiltration. J Hazard Mater 147(3):752-758

Barakat MA, Schmidt E (2010) Polymer-enhanced ultrafiltration process for heavy metals removal from industrial wastewater. Desalination 256(1-3):90-93

Beenakers AACM, Stamhuis EJ, Van Warners A (1994) Kinetics of the hydroxyethylation of starch in alkaline salt-containing aqueous slurries. Ind Eng Chem Res 33:981-992

Bello-Perez LA, Paredes-Lopez O (2009) Starches of some food crops, changes during processing and their nutraceutical potential. Food Eng Rev 1(1):50-65

BeMiller JN, Gray JA (2004) Development and utilization of reflectance confocal laser scanning microscopy to locate reaction sites in modified starch granules. Cereal Chem 81(2): 278-286

BeMiller JN, Gray JA (2005) Influence of reaction conditions on the location of reactions in waxy maize starch granules reacted with a propylene oxide analog at low substitution levels. Carbohydr Polym 60(2):147-162
BeMiller JN, Han J-A (2007) Influence of the reaction conditions on MS values and physical properties of waxy maize starch derivatized by reaction with propylene oxide. Carbohydr Polym 64(2):158-162

BeMiller JN, Huber KC (2001) Location of sites of reaction within starch granules. Cereal Chem 78(2):173-180

Bertolini AC (2010) Starches: Characterization, Properties, and Applications. CRC Press, United States of America

Bicak N, Ozbelge HO, Taralp A, Yllmaz L, Yurum A (2013) High performance ligands for the removal of aqueous boron species by continuous polymer enhanced ultrafiltration. Desalination 320:33-39

Bolto BA (1995) Soluble polymers in water purification. Prog Polym Sci 20:987

Bosch X (2003) Cadmium cuts two ways: the heavy metal mutates DNA, and then prevents cells from repairing the damage. Science 609:1-11

Camarillo R, Perez A, Canizares P, De Lucas A (2012) Removal of heavy metal ions by polymer enhanced ultrafiltration batch process modeling and thermodynamics of complexation reactions. Desalination 286:193-199

Chabot JF, Hood LF (1976) Interaction of iron compounds with starch granules. Wiley, New York, NY, pp 264-267

Chang JE, Chang YK, Chen TC, Chiang LC, Lu HC, Shih PH (2007) Removal of heavy metal by insoluble starch xanthate. Environ Inform Arch 5:684-689

Doane WM, Russell CR, Wing RE (1975) Insoluble starch xanthate: use in heavy. Metal removal. J Appl Polym Sci 19(3):847-854

Doane WM, Rayford WE, Wing RE (1978) Carboxyl-containing starch graft polymer: preparation and use in heavy metal removal. J Appl Polym Sci 24(1):105-113

Eilers H (1936) On high polymeric compounds, news: the strong construction structure. About Dep Chem 69:819-848 (in German)

Hoover R (2001) Composition, molecular structure, and physicochemical properties of tuber and root starches: a review. Carbohydr Polym 45(3):253-267

Hu Z, Ye H, Zeng J (2009) Application of the hybrid complexationultrafiltration process for metal ion removal from aqueous solutions. J Hazard Mater 161(2-3):1491-1498

Islamoglu S, Yilmaz L (2006) Effect of ionic strength on the complexation of polyethyleneimine (PEI) with $\mathrm{Cd}^{2+}$ and $\mathrm{Ni}^{2+}$ in polymer enhanced ultrafiltration (PEUF). Desalination 200(1-3):288-289

Kadioglu SI, Ozbelge HO, Yilmaz L (2009) Estimation of binding constants of $\mathrm{Cd}(\mathrm{II}), \mathrm{Ni}(\mathrm{II})$ and $\mathrm{Zn}$ (II) with polyethyleneimine (PEI) by polymer enhanced ultrafiltration (PEUF) technique. Sep Sci Technol 44(11):2559-2581

Khaidar MS, Labanda J, Llorens J (2009) Feasibility study on the recovery of Chromium(III) by polymer enhanced ultrafiltration. Desalination 249(2):577-581

Kim BS, Lim ST (1999) Removal of heavy metal ions from water by cross-linked carboxymethyl corn starch. Carbohydr Polym 39:217-223

Kozuka H, Kuroki N, Okuda S, Takagishi T (1985) Binding of Metal Ions by polyethyleneimine and its derivatives. J Polym Sci 23:2109

Lim S, Seib PA (1993) Location of phosphate esters in a wheat starch by ${ }^{31} \mathrm{P}$-nuclear magnetic resonance microscopy. Cereal Chem 70(2): $145-152$

Malaysia, DOE (1994) Malaysia environmental quality act report. Ministry of Science, Technology and Environment, Malaysia

Malaysia, DOE (2011) Malaysia environmental quality report. Ministry of Natural Resources and Environment, Malaysia 
Ozbelge HO, Uludag Y, Yilmaz L (1997) Removal of mercury from aqueous solutions via polymer-enhanced ultrafiltration. J Membr Sci 129(1):93-99

Pereira ED, Rivas BL, Villoslada IM (2003) Water-soluble polymer-metal ion interactions. Prog Polym Sci 28(2):173-208
Seib P, Wu Y (1990) Acetylated and hydroxyprpoylated distarch phosphates from waxy barley: paste properties and freeze-thaw stability. Cereal Chem 67:202-208 